\title{
Hepatoprotective and antioxidant activity of ethanolic leaves extract of Avicennia marina against alcohol-induced liver toxicity in rats
}

\author{
K Vellimalai*, G Dinesh Kumar, K Jayaseelan \\ Department of Zoology and Biotechnology, A.V.V.M. Sri Pushpam College, (Autonomous) Thanjavur, Tamil Nadu, India
}

\section{ABSTRACT}

Plants play an important role in the life of human, as the major source of food, as well as for the maintenance and improveme nt of health and for the elimination of the enemies since ages. Plants are the basic source of knowledge of modern medicine. The present study was conducted to evaluate the hepatoprotective activity of ethanolic leaves extract of Avicennia marina are evaluated in alcohol induced hepatotoxicity in rats. Silymarin $(100 \mathrm{mg} / \mathrm{kg})$ was given as reference standard. The ethanolic leaves extract of Avicennia marina have shown very significant hepatoprotection against alcohol induced hepatotoxicity in albino rats in reducing SGOT, SGPT, Alkaline phosphatase (ALP) and GGT and levels of total bilirubin and total protein were investigated and showed an increase in alcohol induced rats when compared to control. The extracts of the test plant exhibited significant $(\mathrm{p}<0.01)$ hepatoprotective activity against the alcohol induced liver models by improving liver function which was indicated by reduction in the levels of SGOT, SGPT, ALP, GGT, total bilirubin and total protein.
\end{abstract}

Keywords: Avicennia marina, Hepatoprotective, Liver Enzymes, Silymarin

Article Info: Received 04 July 2019; Review Completed 13 Aug 2019; Accepted 22 Aug 2019; Available online 30 Aug 2019

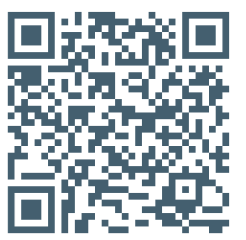

\section{Cite this article as:}

Vellimalai K, Dinesh Kumar G, Jayaseelan K, Hepatoprotective and antioxidant activity of ethanolic leaves extract of Avicennia marina against alcohol-induced liver toxicity in rats, Journal of Drug Delivery and Therapeutics. 2019; 9(4A):403-408 http://dx.doi.org/10.22270/jddt.v9i4-A.3500

K Vellimalai, Assistant Professor, PG and Research Department of Zoology \&Biotechnology, A.V.VM Sri Pushpam College (Autonomous), Poondi - 613503, Thanjavur (Dt) Tamilnadu, India.

\section{INTRODUCTION:}

Mangrove plant extracts have been used for centuries as a popular method for treating several health disorders. Plant derived substances have recently become of great interest owing to their versatile applications. Mangroves are biochemically unique, producing a wide array of novel natural products. These medicinal plants are of great importance for healthy living of an individual [1]. Nowadays days liver diseases are one of the serious health problems. It is a key organ for detoxification of toxic substance and disposition of endogenous substances. It is continuously and widely exposed to toxins and chemotherapeutic agents that lead to impairment of its functions [2]. All types of liver injuries leads to damage of hepatocytes which results in its mal-functioning. Alcoholic liver disease is a worldwide health problem which has three manifestations in form of fatty liver/steatosis, alcoholic hepatitis and liver cirrhosis. Atleast $80 \%$ of chronic alcoholic consumers may develop steatosis, $10-35 \%$ alcoholic hepatitis and approximately 10\% liver cirrhosis. Intake of alcohol causes accumulation of reactive oxygen species (ROS) like superoxide, hydroxyl radical and hydrogen peroxide in the hepatic cells that oxidize the glutathione which leads to lipid peroxidation of cellular membranes, oxidation of protein and DNA resulting in hepatic damage [3].A number of Indian medicinal plants have been used for thousands of years in the traditional system of medicine, Ayurveda. These plants have been used for the management of hepatitis and liver damage. The liver supports almost every organ in the body and is vital for survival. Because of its strategic position and multidimensional functions, the liver is also prone to many diseases. .A.marina (Forssk.) Vireh as a pioneer tree species of mangrove which belonging to the family (Avicenniaceae) It is an cosmopolitan species widely distributed along tropical and subtropical coastlines. [4]. It is commonly known as gray mangrove tree. Mangroves contain important chemical constituents with potential medicinal properties. A. marina has been used traditionally for treatment of ulcers and skin diseases. The barks, leaves, fruits and gum of this species have been used as traditional medicine in many parts of the world to treat skin and toothache diseases .Several chemical Components were isolated from the different parts of $A$. marina by natural chemists. A. marina extracts possess diverse biological activities such as mosquito larvicides and show anti-inflammatory, anti-carcinogenic and antiatherosclerotic activities. [5-7].Hence in the present study is concerned Hepatoprotective and antioxidant activity of ethanolic extract of leaves of Avicennia marina against alcohol-induced liver injury in rats. 


\section{AND METHODS}

Collection, Identification and Authentication of selected plant:

Fresh, healthy and young leaves of Avicennia marina were collected from Muthupet, Thiruvarur district, Tamilnadu, India and authenticated by professionals in Department of Botany, St. Joseph's College, Tiruchirappalli, India. The herbarium number of the plant is KM 001.

\section{Preparation of plant extracts:}

The leaves were cleaned and dried in shade for 7 days and then ground well to fine powder. About $500 \mathrm{~g}$ of dry powder was extracted with ethanol $(80 \%)$ at $70^{\circ} \mathrm{C}$ by continuous hot percolation using soxhlet apparatus. The extraction was continued for $24 \mathrm{hrs}$. The ethanolic extract was then filtered and kept in hot air oven at $40^{\circ} \mathrm{C}$ for $24 \mathrm{hrs}$ to evaporate the ethanol from it. A dark brown residue was obtained. The residue was kept separately in air tight containers and stored in a deep freezer.

\section{Pharmacological Studies}

\section{Animals:}

Healthy, matured male albino wistar rats weighing 170-210g were used for the present study. They were kept in plastic animal cages at animal house maintained at standard temperature and humidity with $12 \mathrm{~h}$ light and dark cycle. The animals were fed with standard pellet diet and water. The animals are handled according to Good Laboratory Practice (GLP). After one week of acclimatization, the animals were used for further research experiments. The ethical clearance was obtained from institutional animal ethical committee as per the Indian CPCSEA guidelines (CPCSEA/265).

\section{Acute toxicity studies}

The acute toxicity study was carried out as per the guidelines set by OECD-423, received from Committee for the Purpose of Control and Supervision of Experiments on Animals, Ministry of Social Justice and Empowerment, Government of India[8].Wistar rats $(n=6)$ of either sex were selected by a random sampling technique for the acute toxicity study. The animals were fasted overnight prior to the experiment and maintained under standard laboratory conditions. The extract was administrated orally in increasing dose up to $2000 \mathrm{mg} / \mathrm{kg}$.

\section{Groupings and Experimental Design}

The animals were divided into four groups. Each group contained six animals.

Group I :Normal control $(\mathrm{n}=6$, the animals were given normal saline only)

Group II :Hepatotoxic control $(n=6$, the animals were given $1 \mathrm{ml}$ of $20 \%$ alcohol for 21 days)

Group III :Treatment group ( $\mathrm{n}=6$, the animals were given 1 $\mathrm{ml}$ of $20 \%$ alcohol for 21 days and from $22^{\text {nd }}$ to $42^{\text {nd }}$ days the extract of A.marina was given to animals through the intragastric tube $(100 \mathrm{mg} / \mathrm{Kg}$ b. wt)

Group IV :Treatment group ( $n=6$, the animals were given $1 \mathrm{ml}$ of $20 \%$ alcohol for 21 days and from $22^{\text {nd }}$ to $42^{\text {nd }}$ days the animals were given silymarin drug through intragastric tube $(1 \mathrm{~g} / \mathrm{kg} . \mathrm{b} . \mathrm{wt})$.

At the end of the drug treatment period, all the animals were anaesthetized by application of light chloroform and blood samples were collected from a group of animals from dorsal aorta by heparinized syringe in vacutainer tubes. Plasma was separated from the collected blood by centrifugation of $3000 \mathrm{rpm}$ for 5 minutes. Separate blood samples were collected from another group of anaesthetized animals in glass test tubes and allowed to coagulate for 30 mins. Serum was separated by centrifugation at $3000 \mathrm{rpm}$ for $2 \mathrm{~min}$. Plasma and serum samples were kept at $-20^{\circ} \mathrm{C}$ for biochemical analysis.

Finally the animals were sacrificed by cervical decapitation, the perfused liver of each animal was dissected out and washed with isotonic solution and then homogenized to get 11 per cent solution of tissue homogenate in Tris Hcl buffer $(10 \mathrm{~mm}, \mathrm{pH}$ 8.0). This homogenate was used for the determination of various parameters.

\section{Assay of Hepatic enzymes}

The clear serum obtained after centrifugation was used for the estimation of serum alanine aminotransferase (ALT), aspartate aminotransferase (AST), alkaline phosphatase (ALP), Gamma Glutamyl Transferase (GGT) and total serum bilirubin (SB) [9-12].

\section{Evaluation of antioxidants}

The enzymatic antioxidants such as superoxide dismutase (SOD), catalase (CAT), and glutathione (GSH) peroxidase (GPx) [13-15] and the non-enzymatic antioxidants such as GSH, vitamin $\mathrm{E}$, vitamin $\mathrm{C}$, and thiobarbituric acid reactive substances (TBARS) [16-19] are evaluated.

\section{Histological Studies}

Liver slices were fixed in $10 \%$ formalin and embedded in paraffin wax. Sections of 5 micron thickness were made using a microtome and stained with haematoxylin- eosin and observed under microscope. Photographs of each of the slides were taken at $40 x$ magnification.

\section{Statistical analysis}

The data were statistically analyzed and all values were expressed as mean \pm SEM. The data were also analyzed by One Way ANOVA using SPSS Software. $\mathrm{P}<0.05$ was considered significant.

\section{RESULTS}

\section{Phytochemical analysis:}

\section{Qualitative analysis:}

The qualitative phytochemical analysis of ethanolic extracts of A.marina leaves revealed the presence of alkaloids, flavonoids, steroids, cardiac glycosides, anthraquinones, tannins, terpenoids and absence of saponins and protein (Table 1)

\section{Hepatoprotective Enzymes:}

Hepatoprotective effects in terms of activities of hepatic enzymes such as Serum glutamic oxaloacetic transaminase (SGOT), Serum glutamic pyruvic transaminase (SGPT), Alkaline phosphatase (ALP), Gamma glutamate transpeptidase (GGT), levels of total bilirubin and total protein were investigated and showed an increase in alcohol induced rats when compared to control. The extracts of the test plant exhibited significant ( $p<0.05)$ hepatoprotective activity against the alcohol induced liver models by improving liver function which was indicated by reduction in the levels of SGOT, SGPT, ALP, GGT, total bilirubin and total protein (Table 2). 
The levels of SGOT, SGPT, ALP, GGT, total bilirubin and protein were $102.16 \pm 3.66,72.32 \pm 0.58,38.78 \pm 0.43,16.61$ $\pm 0.23,0.71 \pm 0.01$ and $5.28 \pm 0.26$ respectively with A.marina administrated rat models. Here also the treatment of A.marina increased the hepatoprotective activity (Table 2).

\section{Antioxidant activities:}

\section{Enzymatic antioxidant activities}

The levels of antioxidant enzymes such as Superoxide dismutase (SOD), Lipid peroxides (LPO), Catalase (CAT), Glutathione (GSH), Glutathione peroxidase (GPx) and Glutathione-S-Transferase (GST) in the normal and experimental animals were studied and given in Table 3.

Table 1: Qualitative phytochemical analysis Avicennia marina

\begin{tabular}{|c|c|c|c|}
\hline S.No & Tests & Appearance & Results \\
\hline 1. & Alkaloids & Pale precipitate & + \\
\hline 2. & Flavonoids & Dirty brown color & + \\
\hline 3. & Cardiac glycosides & Brown ring formation & + \\
\hline 4. & Steroids & Violet to blue color & + \\
\hline 5. & Terpenoids & Reddish brown color & + \\
\hline 6. & Tannins & Yellow precipitate & + \\
\hline 7. & Anthraquinones & Red color & + \\
\hline 8. & Protein & Absence of pink red color & + \\
\hline 9. & Saponins & Absence of honey comb like froth & + \\
\hline
\end{tabular}

Table 2: Hepatic enzyme activities of A.marina leaves extracts

\begin{tabular}{|l|c|c|c|c|}
\hline \multirow{2}{*}{\multicolumn{1}{|c|}{ PARAMETERS }} & \multicolumn{4}{c|}{ EXPERIMENTAL GROUPS } \\
\cline { 2 - 5 } & $\begin{array}{c}\text { Group I } \\
\text { (Control) }\end{array}$ & $\begin{array}{c}\text { Group II } \\
\text { (Alcohol) }\end{array}$ & $\begin{array}{c}\text { Group III } \\
\text { A.marina 100 } \\
\text { mg/kg) }\end{array}$ & $\begin{array}{c}\text { Group IV } \\
\text { (Alcohol + } \\
\text { Silymarin) }\end{array}$ \\
\hline SGOT (IU/L) & $34.91 \pm 0.33$ & $178.42 \pm 4.25$ & $102.16 \pm 3.66^{*}$ & $86.75 \pm 1.44^{* * *}$ \\
\hline SGPT (IU/L) & $29.12 \pm 0.93$ & $127.08 \pm 1.23$ & $72.32 \pm 0.58^{*}$ & $50.33 \pm 0.60^{* * *}$ \\
\hline ALP (IU/L) & $28.94 \pm 1.41$ & $81.03 \pm 1.30$ & $38.78 \pm 0.43^{* * *}$ & $34.46 \pm 2.42^{* * *}$ \\
\hline GGT (IU/L) & $31.06 \pm 0.10$ & $58.23 \pm 0.68$ & $16.61 \pm 0.23^{* * *}$ & $16.21 \pm 0.15^{* * *}$ \\
\hline Total Bilirubin $(\mathrm{gmol}-1)$ & $0.21 \pm 0.11$ & $1.39 \pm 0.08$ & $0.71 \pm 0.01^{* *}$ & $0.46 \pm 0.01^{* * *}$ \\
\hline Serum protein $(\mu \mathrm{g})$ & $6.92 \pm 0.33$ & $3.53 \pm 0.10$ & $5.28 \pm 0.26^{* *}$ & $5.78 \pm 0.52^{* * *}$ \\
\hline
\end{tabular}

Values are mean \pm SEM $(n=6)$ One Way ANOVA, where,

* represents significant at $\mathrm{P}<0.05 \quad * *$ represents highly significant at $\mathrm{P}<0.01$

*** represents very significant at $\mathrm{P}<0.001$ All values are compared with toxicant.

Table 3: Antioxidant activities of A.marina leaves extracts

\begin{tabular}{|l|c|c|c|c|}
\hline \multirow{2}{*}{ PARAMETERS } & \multicolumn{3}{|c|}{ EXPERIMENTAL GROUPS/ Enzymatic antioxidant } \\
\cline { 2 - 5 } & Group I (Control) & $\begin{array}{c}\text { Group II } \\
\text { (Alcohol ) }\end{array}$ & $\begin{array}{c}\text { Group III } \\
\text { (A.marina 100 mg/kg) }\end{array}$ & $\begin{array}{c}\text { Group IV } \\
\text { (Alcohol + Silymarin) }\end{array}$ \\
\hline SOD (units / mg protein) & $12.48 \pm 0.55$ & $3.58 \pm 0.26$ & $7.3 \pm 0.201^{* *}$ & $8.47 \pm 0.46^{* * *}$ \\
\hline LPO $(\mu \mathrm{mol} / \mathrm{L})$ & $4.31 \pm 0.07$ & $9.29 \pm 0.00$ & $7.6 \pm 0.201$ & $6.59 \pm 0.15^{*}$ \\
\hline $\begin{array}{l}\text { CAT }\left(\mathrm{N} \mathrm{moles} \mathrm{of} \mathrm{H}_{2} \mathrm{O}_{2}\right. \\
\text { decomposed min/mg/protein) }\end{array}$ & $93.8 \pm 1.42$ & $28.63 \pm 0.40$ & $59.44 \pm 1.81^{* *}$ & $82.14 \pm 1.68^{* * *}$ \\
\hline GSH $(\mu \mathrm{mol} / \mathrm{L})$ & $18.87 \pm 0.07$ & $8.01 \pm 0.04$ & $14.93 \pm 0.05^{* * *}$ & $15.42 \pm 0.04^{* * *}$ \\
\hline $\begin{array}{l}\text { GPx }(\mathrm{m} \text { moles of GSH } \\
\text { oxidized/mim/mg/protein) }\end{array}$ & $13.96 \pm 0.83$ & $6.51 \pm 0.47$ & $10.87 \pm 0.67^{* * *}$ & $11.29 \pm 0.10^{* * *}$ \\
\hline $\begin{array}{l}\text { GST }(\mathrm{m} \mathrm{moles} \mathrm{of} \mathrm{CDNB} \\
\text { conjugated/min/mg/protein) }\end{array}$ & $98.35 \pm 0.02$ & $49.70 \pm 0.01$ & $72.08 \pm 0.10^{* *}$ & $88.79 \pm 0.03^{* * *}$ \\
\hline Vitamin $\mathrm{E}(\mathrm{mg} / \mathrm{dl})$ & $1.50 \pm 0.09$ & $0.65 \pm 0.03$ & $1.49 \pm 0.08^{* * *}$ & $1.48 \pm 0.07^{* * *}$ \\
\hline Vitamin C $(\mu \mathrm{mol} / \mathrm{L})$ & $1.28 \pm 0.07$ & $0.57 \pm 0.03$ & $1.03 \pm 0.09^{* * *}$ & $0.89 \pm 0.06^{* *}$ \\
\hline
\end{tabular}

Values are mean \pm SEM $(n=6)$ One Way ANOVA, where,

* represents significant at $\mathrm{P}<0.05 \quad * *$ represents highly significant at $\mathrm{P}<0.01$

*** represents very significant at $\mathrm{P}<0.001 \quad$ All values are compared with toxicant. 
The antioxidant enzyme superoxide dismutase level showed a significant decrease $(3.58 \pm 0.26)$ in alcohol intoxicated rats while the rats treated with extracts of A.marina exhibited a significant increase in the level of SOD over the alcohol intoxicated rats. The leaves extract of A.marina increased the SOD level significantly $(7.3 \pm 0.201)$ when compared to the alcohol induced animal.

Alcohol intoxicated rats showed a high level (9.29 \pm $0.00)$ of lipid peroxidase over control $(4.31 \pm 0.07)$. The extracts of medicinal plant, A.marina, significantly reduced the level of LPO in alcohol intoxicated animals and the levels were $7.6 \pm 0.201$. The animals those received the extract of A.marina showed a significant reduction in LPO level as compared to alcohol intoxicated animals.

Inhibition of catalase activity was observed in alcohol intoxicated rats when compared to control. The administration of drugs of A.marina, in alcohol induced rats, elevated the catalase activity considerably in the liver tissues and the increase in activity was more in animals treated with A.marina (59.44 \pm 1.81$)$.

The enzymatic antioxidants such as Reduced Glutathione, Glutathione peroxidase and Glutathione-STransferase levels were declined in the ethanol induced rats when compared to normal rats. The treatment of alcohol intoxicated animals with drugs of A.marina revealed an enhancement in their levels over alcohol induced ones. The levels of GSH, GPx and GST on $42^{\text {nd }}$ day were $14.93 \pm 0.05$, $10.87 \pm 0.67$ and $72.08 \pm 0.10$ respectively with A.marina

\section{Non-enzymatic antioxidant activities}

\section{Vitamin E and C}

The non-enzymatic antioxidants such as vitamins $\mathrm{E}$ and $\mathrm{C}$ levels were estimated in control, alcohol intoxicated and extract administrated in addition to standard drug
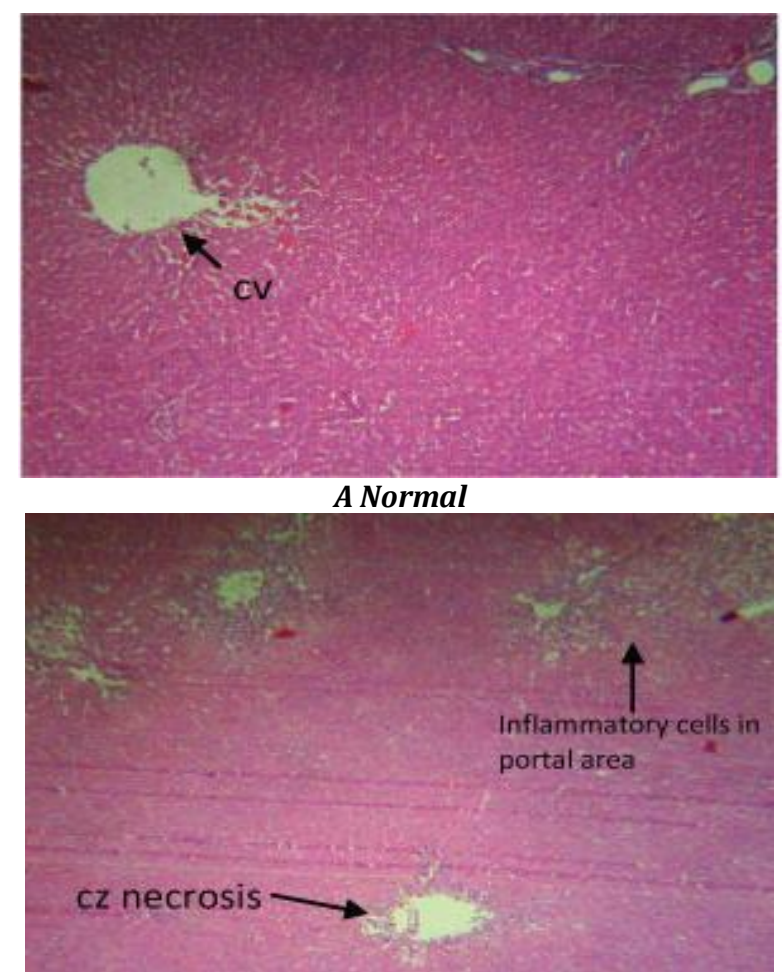

B. Alcohol toxicant treated animals. Their levels were significantly decreased in alcohol intoxicated animals as compared to control. On the other hand, plant extracts administrated animals showed higher levels of these non-enzymatic antioxidants over alcohol intoxicated animals. Interestingly, the extract of A.marina increased the level of both vitamins in alcohol intoxicated animals over the standard drug, silymarin (Table 3).

\section{Histopathological Study:}

In histological studies, liver section of normal (control) rats showed normal hepatocytes with wellpreserved cytoplasm. There was no sign of inflammation, fatty change or necrosis in these animals (Figure1-A). Severe inflammations and cell swelling were observed in endothelial liver cells of alcohol treated rats and they also showed vacuoles in the cytoplasm as well as ballooning and degeneration of hepatocytes (Figure 1-B).

The liver section of A.marina (100 mg/kg. b.wt) treated rats showed higher recovery of inflammatory cells around portal tract. There were few portal traid with periportal lymphocytic infiltration, central vein and rest of the hepatic parenchyma appeared unremarkable. No centrizonal necrosis was identified (Figure 1-C).

Silymarin treated animal groups showed a normal liver lobule with no sign of necrosis in the centrizonal area and portal triad, only focal periportal inflammation was observed (Figure 1-D). A.marina was more effective in hepatoprotective activity.

Hence, from the results of phytochemical analysis, haematological parameters, antioxidant activities, hepatoprotective activities and histopathological studies, it is clear that, A.marina had more potentiality in alcohol induced albino rats when compared to standard drug silymarin.

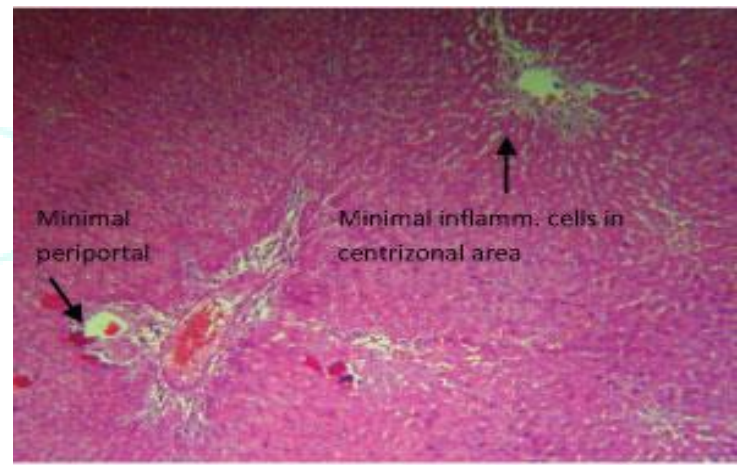

C. $100 \mathrm{mg} / \mathrm{Kg}$ b. wt Plant leaves Extract

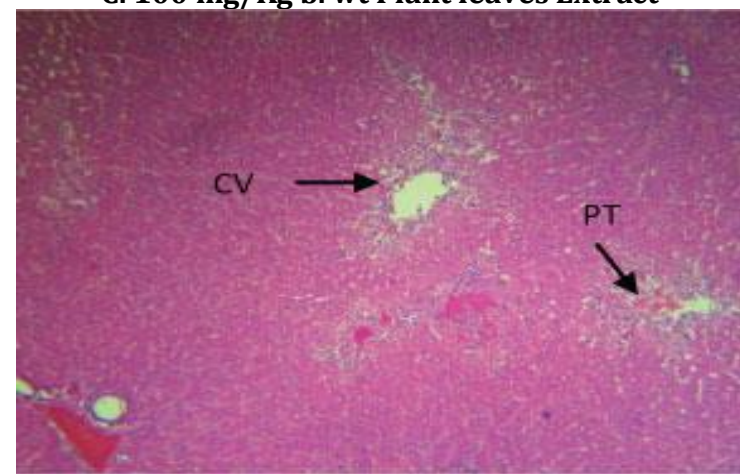

D. Silymarin Drug

Figure 1: Histopathological liver sections 


\section{DISCUSSION:}

Alcohol related disorders are one of the challenging current health problems with far reaching medical, social and economic consequences. Long term use of alcohol potentially results in serious illness, including alcoholic fatty liver, hyperglyceridaemia, cirrhosis, cardiovascular disease and inflammation of the pancreas [20].Natural products can be selected for biological screening based on ethno medical use of plants, because many infectious diseases are known to have been treated with herbal remedies throughout the history of mankind Mangrove plants have been used in folklore medicines and extracts from mangrove species have proven activity against human, animal and plant pathogens. Some of the mangrove plant extract contains essential secondary metabolites like alkaloids, phenolics, steroids, terpenoids have been characterized from mangroves and have toxicological, pharmacological and ecological importance. Plant-derived substances have recently become of great interest owing to their versatile applications [21].

Serum marker enzymes SGPT, SGOT, ALP, GGT and serum proteins are most sensitive markers employed in the diagnosis of liver damage because these are cytoplasmic in location and are released in to the circulation after cellular damage. [22]. During liver damage, cellular enzymes like SGPT, SGOT, GGT and ALP leak into the serum, resulting in increased concentrations [23]. In the present investigation it was observed that the animals treated with alcohol resulted in significant hepatic damage as shown by the elevated levels of serum markers. These changes in the marker levels will reflect in hepatic structural integrity. The levels of these enzymes are elevated in the alcohol induced groups which are corresponded to the wide-ranging liver damage induced by the toxin. The reduced concentrations of ALT, AST, ALP, GGT and serum proteins were observed in the group administered with ethanolic leaves extract of $A$. marina remarkably prevented alcohol-induced hepatotoxicity and control the level of marker enzymes.

Bilirubin is one of the most useful clinical clues to the severity of necrosis and its accumulation is a measure of binding, conjugation and excretory capacity of hepatocyte. Serum bilirubin is considered as one of the true test of liver functions since it reflects the ability of the liver to take up and process bilirubin into bile. Elevated levels may indicate several illnesses [24]. High levels of total bilirubin in alcohol treated rats may be due to alcohol toxicity. This may have resulted in hyperbilirubinemia. In the present study, the oral administration of ethanolic leaves extract of A. marina treated groups shows decreased level of bilirubin when compared to alcohol-induced rats. Hence, this study reveals that leaves of $A$. marina have a potent hepatoprotective activity.

Antioxidants of plant origin are believed to help protect the cells from free radical damage. It has the ability to protect the body from oxidative damage. Radical scavenging activities are very important due to the deleterious role of free radicals in biological systems. The enzymatic antioxidant is the nature protector against lipid peroxidation. SOD, CAT, and GPx enzymes are important scavengers of hydrogen peroxide and superoxide ion. These enzymes prevent generation of hydroxyl radical and protect the cellular constituents from oxidative damage [25] A number of studies have shown that antioxidants including the plant extracts protect against ethanol hepatotoxicity by inhibiting lipid peroxidation and enhancing antioxidant enzyme activity. [26].In the present investigation showed decreased activities of CAT, SOD and GPx as well GSH in alcohol treated rats were observed. Since alcohol is a hepatotoxicant which induces oxidative damage, the levels of liver antioxidant enzymes SOD, CAT, GPx were measured. The toxicant group showed reduced levels of antioxidant enzymes as compared to Normal Control Group. Administration of A. marina plant extract significantly raised the antioxidant enzymes when compared with the Toxicant group. Silymarin treated group showed similar hepatoprotective effect.

Glutathione, a major non-protein thiol in living organisms and plays a central role in coordinating the body's antioxidant defense processes. Excessive peroxidation causes increased glutathione consumption. Reduced thiols have long been reported to be essential for recycling of antioxidants like vitamin $C$ and vitamin E [27]. Ascorbic acid (vitamin C) is the most abundant, powerful and water soluble antioxidant acts to prevent or in minimizing the damage caused by ROS in plants. Vitamin C is regard as the first line natural antioxidant defense in plasma and a powerful inhibitor of LPO [28]. Tocopherols (vitamin E) a lipid soluble antioxidant are considered as potential scavengers of ROS and lipid radicals [29]. Tocopherols are considered as a major antioxidant in bio membranes, where they play both antioxidant and non-antioxidant functions [30].In the present reports non enzymatic antioxidants GSH, vitamin $C$ and vitamin $E$ are elevated in the alcohol toxicant group. The oral administrations of leaves extract of A.marina enhance the GSH, vitamin C and vitamin E. From the results it can be realized that A.marina prevented the manifestation of alcohol induced hepatotoxicity in dose dependent manner and upon comparison of the tissue-antioxidant parameters on the basis of kg-body-weight doses of the extracts administered, A.marina offered better protection than standard drug even though the difference is not much significant.

\section{Histopathology}

Histopathology reports reveal that administration of alcohol induced group shows various degradation of fatty cysts, infiltration of lymphocytes and proliferation of kuffer cells and congestion of liver sinusoids. This further confirms that alcohol induced group cause hepatotoxicity. The ethanolic leaves extract of A.marina administrated group shows decreased levels of biochemical markers like SGPT, SGOT, ALP and Total bilirubin levels in a dose dependent manner. Similarly, histopathological observations show that hepatic globular architecture was normalized; fewer lymphatic infiltrations were seen kuffer cells proliferation appears normal. These observations concluded that the ethanolic leaves extract of A.marina possess hepatoprotective activity against alcohol induced hepatotoxicity. Hence this study plant drugs are known to play a vital role in the management of liver diseases. Based upon the result of this present study, it can be concluded that ethanolic leaves extract of A.marina has proven itself as a significant hepatoprotective as well as a considerable antioxidant.

\section{CONCLUSION}

The medicinal plant bioactive compounds will help to develop new therapeutically agents. The results obtained from present study shows that this plant is a good natural source for hepatoprotective activity. As this plant is easily available and the ethanol extract is showing better activity, this suggests that this plant is a cost effective natural treatment and no side effects. Further clinical trials should be done in order to develop a prominent formulation that will be useful for public. As the cost of the treatment is rising, developing a cost effective remedies will definitely 
give a better option and opportunities to treat chronic diseases.

\section{CONFLICT OF INTEREST}

interest.

The authors declare that there are no conflicts of

\section{ACKNOWLEDGMENT}

The authors are very grateful to the Secretary, Correspondent and the Principal of A.V.V.M. Sri Pushpam College (Autonomous), Poondi - 613 503, Thanjavur (Dt.) and also thankful to Mr. R. J. Antony Raj, the Chairman, SIMPRA Research Institute for providing the excellent infrastructure and necessary facilities. We are also very grateful to University Grants Commission (UGC), Government of India, New Delhi, for providing financial assistance in the form of Rajiv Gandhi National Fellowship, which buttressed me to perform my work comfortably.

\section{REFERENCES:}

1. Dinesh Kumar G, Jayaseelan T, Senthil J, Mani P. Evaluation Of Hepatoprotective and Antioxidant Activity Of Avicennia Alba (Blume)On Paracetamol-induced Hepatotoxicity In Rats. Innov J Ayruvedic Sci, 2016;4(3): 19-22.

2. Bandaranayake, W. M. Traditional and medicinal uses of mangroves. Mangroves and Salt Marshes, 1998, 2, 133-148

1. R.Vijayaraj, K.Naresh Kumar, P.Mani, J.Senthil, G.Dinesh Kumar and T.Jayaseelan. Green Synthesis of Silver Nanoparticles from Ethanolic Seed Extract of Acranythes aspera (linn.) and its Anti-inflammatory Activities.

International Journal of Pharmacy \& Therapeutics, 2016,7 (1): 42-48.

3. Panda, S., H. Thatoi and S. Dutta, 2009. Antibacterial activity and phytochemical screening of leaf and bark extracts of Vitex negundo L. from Similipal biosphere reserve, Orissa. J. Med. Plant Res., 3: 294-300.

4. Kathiresan k Bingham BL (2001) Biology of mangroves and mangrove ecosystems. Adv Mar Biol 40, 81-251.

5. Bandaranayake WM (1998) Traditional and medicinal uses of mangroves. Mangroves Salt Marshes 2, 133-48.

6. Mouafi, F.E., Aziz, S.M., Bashir, A.A.and Fyiad .A.A 2014: Phytochemial Analysis and Antimicrobial Activity of Mangroves Leaves Against Some Pathogens. World Applied Sciences Journal 29(4):547 - 554.

7. Organisation for Economic Co-operation and Development. OECD guideline for testing of chemicals. Acute oral toxicityacute toxic class method. OECD Guidelines for the Testing of Chemicals.Health effects 2010; 1(4): 1-14.

8. Reitman S, Frankel S. A colorimetric method for the determination of serum glutamic oxalacetic and glutamic pyruvic transaminases. Am J Clin Pathol 1957;28(1):56-63.

9. King EJ, Armstrong AR. A convenient method for determining serum and bile phosphatase activity. Can Med Assoc J 1934;31(4):56-63.
10. Fiala S, Fiala AE, Dixon B.Gamma glutamyl transpeptidase in chemically induced rat hepatomas and spontaneous mouse hepatomas.J Natl Cancer Inst 1972; 48:1393-1409.

11. Malloy HT, Evelyn EA. The determination of bilirubin with photoelectric calorimeter. J Biol Chem 1937;119:481-5.

12. Kakkar P, Das B, Viswanathan PN. A modified spectrophotometric assay of superoxide dismutase. Indian J Biochem Biophys 1984;21(2):130-2.

13. Sinha AK. Colorimetric assay of catalase. Anal Biochem 1972;47(2):389-94.

14. Rotruck JT, Pope AL, Ganther HE, Swanson AB, Hafeman DG Hoekstra WG. Selenium: Biochemical role as a component of glutathione peroxidase. Science 1973;179(4073):588-90.

15. Ellman GL. Tissue sulfhydryl groups. Arch Biochem Biophys 1959;82(1):70-7.

16. Omaye ST, Turnbull JD, Sauberlich HE. Selected methods for the determination of ascorbic acid in animal cells, tissues, and fluids. Methods Enzymol 1979;62:3-11.

17. Baker H, Frankel O, De Angelis B, Feingold S. Plasma $\alpha$ tocopherol in man at various time intervals after ingesting free or acetylated tocopherol. Nutr Rep Int 1980;21:531-6.

18. Niehaus WG Jr, Samuelsson B. Formation of malonaldehyde from phospholipid arachidonate during microsomal lipid peroxidation. Eur J Biochem 1968;6(1):126-30.

19. Ponnappa BC, Rubin E. Modeling alcohol's effect on organs in animal models. Alcohol. Res. Health 2000; 24:93-104.

20. Kokpal V, Miles DH, Payne AM, Chittawong V. Chemical constituents and bioactive compounds from mangrove plants. Stud Nat Prod Chem (1990), 7:175-199.

21. Mitra, S.K., Venkataranganna, M.V., Sundaram, R., Gopumadhavan, S.(1998): Protective effects of HD-03, A herbal formulation, against various hepatotoxic agents in rats. Ethnopharmacol J., 63:181-86.

22. Deb AC. Fundamentals of biochemistry. 7th ed. Kolkata, New Central Book Agency, 1998.

23. Graw A, Cowan R.A, O'Reilly D.S.J, Stevant M.J and Stephard, J. Clinical biochemistry- an illustrated color text. Is ted. New York: Churchill Livingstone. 1999; 51-53

24. Scott MD, Lubin BH, Zuo L, Kuypers FA. Erythrocyte defense against hydrogen peroxide: Preeminent importance of catalase. J Lab Clin Med 1991;118(1):7-16.

25. Rajagopal, S.K., P. Manickam, V. Periyasamy and N. Namasivayam, 2003. Activity of Cassia auriculata leaf extract in rats with alcoholic liver injury. The Journal of Nutritional Biochemistry, 14: 452-458

26. Kayang $\mathrm{H}$, Tribal knowledge on wild edible plants of Meghala Indian A, Northeast India. J. Traditional Knowledge. 2007; 6 suppl 1: 177-181.

27. H.R. Athar, A. Khan, M. Ashraf, Exogenously applied ascorbic acid alleviates salt-induced oxidative stress in wheat, Env. Exp. Bot. 63 (2008) 224-231.

28. Maxwell SRJ. Prospects for use of antioxidant therapies. Drugs.1995; 49: 345-361.

29. H. Hollander-Czytko, J. Grabowski, I. Sandorf, K. Weckermann E.W. Weiler, Tocopherol content and activities of tyrosine aminotransferase and cystine lyase in Arabidopsis under stress conditions, J. Plant Physiol. 162 (2005) 767-770 